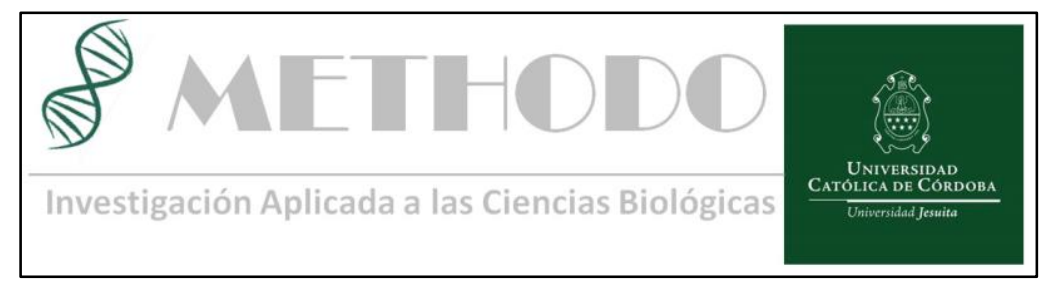

ARTICULO ORIGINAL Methodo 2017;2(4): 126-128

DOI: $10.22529 / \mathrm{me} .2017 .2(4) 07$

Recibido 26 Sep. 2017 | Aceptado 05 Dic. 2017 | Publicado 30 Dic. 2017

\title{
Patología apendicular: de lo frecuente a lo infrecuente *
}

\section{Appendicular pathology: from frequent to infrequent ${ }^{\star}$}

*Trabajo Presentado en las XIV Jornadas de Investigación de la Clínica Universitaria Reina FabiolaOctubre de 2017

\author{
Pantoja Pachajoa DA ${ }^{1}$, Bruno MA ${ }^{1}$, Parodi $\mathrm{M}^{1}$, Viscido $\mathrm{G}^{1}$, Mandojana $\mathrm{F}^{1}$
}

\section{Introducción:}

La apendicitis aguda es la patología más común en el apéndice ${ }^{1}$ y la causa principal del abdomen quirúrgico. $^{2}$

Aproximadamente 300,000 personas se someten a apendicectomía cada año en los Estados Unidos. ${ }^{3}$ El riesgo estimado de presentar un cuadro de apendicitis aguda en algún momento de la vida está estimado en un $7 \% .^{3}$

El uno por ciento de las apendicectomías corresponde a tumores apendiculares. Los tumores malignos se confirman por análisis patológico en 0,9 al $1.4 \%$ de todas las apendicetomías realizadas. ${ }^{4,5}$

Objetivos. Evaluar incidencia de patología apendicular benigna, analizar la incidencia de tumores apendiculares, determinar sobrevida y mortalidad de tumores apendiculares a 5 años.

\section{Pacientes y Métodos.}

Estudio retrospectivo, descriptivo.

Se incluyeron todos pacientes apendicectomizados mayores de 16 años en el servicio de cirugía general de la clínica Universitaria Reina Fabiola desde el $1^{\circ}$ de febrero de 2004 al $1^{\circ}$ de febrero de 2016.

Se excluyeron 78 pacientes con apéndices Negativos.

Se Analizó las variables edad, sexo, tipo histológico del espécimen, el cual se subdividió en congestivo, flegmonoso, gangrenoso, periapendicitis, patología benigna y tumores apendiculares. Se analizó los tumores apendiculares con respecto a la sobrevida y mortalidad.

Análisis Estadístico: se realizó análisis descriptivos de las variables, se expresaron en porcentaje e intervalo de confianza $95 \%$.

\section{Resultados.}

Los pacientes incluidos fueron 1064, 53\% (IC95\%: 50-56\%) (566 pacientes) fueron mujeres y $47 \%$ (IC95\%: 44-50\%) (498 pacientes) de sexo masculino. Del total de pacientes incluidos $872(82 \%)$ eran menores 40 años.

Se los dividió en tres grupos de acuerdo a la patología encontrada: 96,71\% (IC95\%: 95,63-97,77\%) (1029 pacientes) fueron apendicitis aguda, 2,54\% (IC95\%: 1,59$3.49 \%$ ) (27 pacientes) tuvieron patologías benignas y el $0,75 \%, 8$ pacientes, (IC95\%: $0,23-1,27 \%$ ) presentaron tumores apendiculares.

En el análisis anatomopatológico los diagnósticos en el grupo de apendicitis aguda, fueron: flegmonosas en 675 pacientes (65,59\% (IC95\%: 62.69-68.49\%)), congestivas en 229 pacientes $(22,26 \%$ (IC95\%: 19,71-24,79\%)), gangrenosas en 100 pacientes (9.72\% (IC95\%: 7,90-11,52\%)) y 25 individuos tuvieron periapendicitis (2.43\%(IC95\%: 1,48-3,36\%))

En el grupo calificado como patología benigna se encontró 18 pacientes con hiperplasia linfoide, 4 con endometriosis apendiculares, 3 presentaron enfermedad de Crohn, 1 caso de Enterobius vermicularis y 1 paciente con accidente vascular secundario. 
De los ocho pacientes que presentaron tumores apendiculares, 5 eran mujeres y 3 hombres.

El tumor carcinoide fue el más frecuente en esta serie con cuatro casos, los otros cuatro fueron 2 adenocarcinomas y 2 mucoceles. El $62 \%(\mathrm{n}=5)$ de los pacientes con tumores apendiculares tenían menos de 40 años.

Solo a un paciente se le realizó conversión a hemicolectomía derecha.

La sobrevida a 5 años fue del $100 \%$ en todos los pacientes.

\section{Conclusiones.}

El principal diagnóstico en la patología apendicular es la apendicitis aguda.

La patología tumoral del apéndice presenta una muy baja prevalencia, diagnóstico que no impacta en la sobrevida de los pacientes estudiados.

\section{Introduction.}

The acute appendicitis is the most common pathology in the appendix ${ }^{1}$ and the main cause of the surgical abdomen. ${ }^{2}$ Approximately 300,000 people undergo appendectomy each year in the United States. ${ }^{3}$ The life-time risk of acute appendicitis is around $7 \% .^{3}$

One percent of the appendicectomies correspond to appendicular tumors. Malignant tumors are confirmed by pathological analysis in $0.9-1.4 \%$ of all appendectomies performed. ${ }^{4,5}$

Objectives To evaluate the incidence of benign appendicular pathology, to analyze the incidence of appendicular tumors, to determine survival and mortality of appendicular tumors at 5 years.

\section{Patients and Methods.}

Retrospective descriptive study.

All appendectomized patients over 16 years of age were included in the general surgery department of the Clínica Universitaria Reina Fabiola from 1 February 2004 to 1 February 2016.

We excluded 78 patients with negative appendages.

The variables were analyzed: age, sex, histological type of specimen, which was subdivided into congestive, phlegmonose, gangrenous, periapendicitis, benign pathology and appendicular tumors. It was analyzed appendicular tumors regarding survival and mortality.

Statistical analysis: descriptive analyses of variables were performed, expressed as a percentage and $95 \%$ confidence interval.

\section{Results.}

The patients included were $1064.53 \%$ (IC95\%: 50-56\%) (566 patients) were women and 47\% (IC95\%: 44-50\%) (498 patients) were male. Of the total number of patients included, $872(82 \%)$ were under 40 years of age.

They were divided into three groups according to the pathology found: $96.71 \%$ (IC95\%: 95.63-97.77\%) (1029 patients) were acute appendicitis, 2.54\% (IC95\%: 1.59-3.49\%) (27 patients) had benign pathologies and $0.75 \%, 8$ patients, (IC95\%: 0.23-1.27\%) had appendicular tumors.

In the anatomopathological analysis, diagnoses in the acute appendicitis group were: phlegmonoses in 675 patients $(65.59 \%$ (IC95\%: 62.69-68).49\%)), congestive in 229 patients (22.26\% (IC95\%: 19.71-24.79\%)), gangrenous in 100 patients $(9.72 \%$ (IC95\%: $7.90-11.52 \%)$ ) and 25 individuals had periapendicitis (2.43\% (IC95\%: 1.48-3.36\%)). Eighteen patients with lymphoid hyperplasia, four with appendicular endometriosis, three with Crohn's disease, one case of Enterobius vermicularis and one patient with secondary vascular accident were found in the group classified as benign pathology.

Of the eight patients with appendicular tumors, 5 were female and 3 were male.

The carcinoid tumor was the most frequent in this series with four cases, the other four were 2 adenocarcinomas and 2 mucoceles. $62 \%$ $(n=5)$ of patients with appendicular tumors were under 40 years of age.

Only one patient was converted to right hemicolectomy.

The 5 -year survival was $100 \%$ in all patients.

\section{Conclusions.}

The main diagnosis in appendicular pathology is acute appendicitis.

The tumoural pathology of the appendix presents a very low prevalence, a diagnosis that does not impact on the survival of the patients studied.

\section{Bibliografía}

1. Buckius MT. Changing epidemiology of acute appendicitis in the United States: study period 1993-2008. J Surg Res. 2012;175:185-90.

2. Deelder JD. How to treat an appendiceal inflammatory mass: operatively or nonoperatively? J Gastrointest Surg. 2014;18:641-5. 
3. Ma KW, Chia NH, Yeung HW, Cheung MT. If not appendicitis,

then what else can it be? A retrospective review of 1492 appendectomies. Hong Kong Med J 2010;16:12-7

4. Teixeira FJR, Couto Netto SD do, Akaishi EH, Utiyama EM, Menegozzo CAM, Rocha MC. Acute appendicitis, inflammatory appendiceal mass and the risk of a hidden malignant tumor: a systematic review of the literature. World J Emergency Surg. 2017; 12:12. doi:10.1186/s13017-0170122-9.

5. In't Hof $\mathrm{KH}$, van der Wal $\mathrm{HC}$, Kazemier G, Lange JF. Carcinoid Tumour of the Appendix: An Analysis of 1,485 Consecutive Emergency Appendectomies. J Gastrointest Surg. 2008;12(8):14361438. doi:10.1007/s11605-0080545-4.

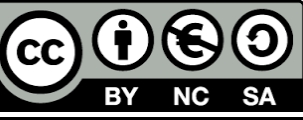

Palabras claves:

APENDICITIS AGUDA, TUMORES APENDICULARES. Keywords:

ACUTE APPENDICITIS, APPENDICULAR TUMORS

\footnotetext{
${ }^{1}$ Servicio de Cirugía General. Clínica Universitaria Reina Fabiola, Universidad Católica de Córdoba, Argentina. Correspondencia: Diana Pantoja Pachojoa. Clínica Universitaria Reina Fabiola. Oncativo 1248 -X5004FHP- Córdoba, Argentina. e-mail: dianaalejandrapantoja@gmail.com
} 